\title{
ÚČETNÍ REFORMA VEŘEJNÝCH FINANCÍ V ČESKÉ REPUBLICE A JEJí VLIV NA ÚČETNICTVÍ, ÚČETNí ZÁVĚRKU, PŘEZKOUMÁNí HOSPODAŘENÍ A AUDIT ÚČETNÍ ZÁVĚRKY NĚKTERÝCH VYBRANÝCH ÚČETNÍCH JEDNOTEK
}

\author{
Jana Hakalová, Alžběta Urbancová \\ Klíčová slova: \\ Reforma účetnictví státu, vybrané a některé vybrané účetní jednotky, vyhlášky, účetní \\ standardy, účetní metody, inventarizace majetku a závazků, účetní závěrka, konsolidovaná \\ účetní závěrka, přezkoumání hospodaření, audit účetní závěrky.
}

\section{Key words:}

State accounting reform, selected and some selected accounting entities, regulations, accounting standards, accounting methods, taking-inventory of assets and liabilities, financial statements, consolidated financial statements, review of the economy of municipalities, audit of financial statements.

\begin{abstract}
Abstrakt
Cílem příspěvku je seznámit čtenáře s platnými právními předpisy pro vedení účetnictví některých vybraných účetní jednotky v letech 2010 a 2011 a také upozornit na problémy $\mathrm{s}$ uplatněním účetních metod $\mathrm{v}$ praxi $\mathrm{v}$ souvislosti s přezkoumáním hospodaření územních samosprávných celků a dobrovolných svazků obcí a auditem účetní závěrky některých vybraných účetních jednotek v kontextu účetní reformy veřejných financí v České republice.
\end{abstract}

\begin{abstract}
The objective of this paper is to give information about the legal regulations for bookkeeping of some selected accounting entities in 2010 and 2011 and also to warn of some problems with the practical application of accounting methods in connection with review of the economy of municipalities and with the audit of financial statements of some selected accounting entities in context of the accounting reform of the public finance in the Czech Republic.
\end{abstract}

\section{Úvod}

Usnesením vlády České republiky č. 561 ze dne 23. 5. 2007 bylo schváleno vytvoření účetnictví státu od 1. 1. 2010. Tímto krokem byla oficiálně zahájena účetní reforma v oblasti veřejných financí. V př́loze k uvedenému usnesení byl formulován základní cíl vzniku účetnictví státu, kterým je vytvoření podmínek pro efektivní zajištění správných, úplných a včasných informací o hospodářské situaci státu a příslušných účetních jednotek. Hlavním záměrem této reformy je zlepšit řízení a kontrolu peněz ve veřejné správě a zároveň sestavovat konsolidovanou účetní závěrku za celý stát. Mezi základní principy účetní reformy veřejných financí v České republice patří zavedení účetních metod ve veřejném sektoru a přiblížit tak vedení účetnictví organizací tohoto sektoru účetnictví podnikatelským subjektům (akruální účetnictví). Projevem reformy jsou změny ve struktuře výkaznictví s důrazem na posílení vypovídací schopnosti celé účetní závěrky ve vztahu k uživatelům. Aplikace akruálního principu - tj. účtování nákladů a výnosů ve věcné a časové souvislosti a kategorizace jednotlivých položek výnosů a nákladů s cílem získání informace o dosaženém výsledku hospodaření umožňuje vedle salda rozpočtu hodnotit efektivitu účetní jednotky. 
Tvorba opravných položek, zavedení metody odpisování majetku vede k zreálnění hodnot vykazovaného majetku v rozvaze a promítnutí budoucích rizik se v účetnictví realizuje pomocí rezerv. Cílem tohoto příspěvku je vymezit legislativu a základní změny, které účetní reforma veřejných financí v České republice přinesla od 1. 1. 2010. Při zpracování příspěvku byla použita metoda popisu, analýzy, komparace a syntézy.

\section{Právní předpisy}

\subsection{Zákon o účetnictví}

V návaznosti na Usnesení vlády České republiky č. 561 ze dne 23. 5. 2007 byl zpracován Harmonogram prací na vytvoření účetnictví státu a na jeho základě byl vypracován návrh změn zákona o účetnictví. Dnem 1. 1.2009 vstoupil v účinnost zákon č. 304/2008 Sb., kterým se změnil zákon č. 563/1991 Sb., o účetnictví. Tímto zákonem byl nastaven právní rámec pro vznik účetnictví státu s účinností k 1. 1. 2010, resp. pro celou účetní reformu v oblasti veřejných financí. Významnou novelou zákona o účetnictví pro některé vybrané účetní jednotky představuje zákon č. 410/2010 Sb., jehož účinnost nastala dnem 1. 1. 2011. Po tomto datu proběhly ještě další 2 méně významné novely zákona o účetnictví.

Novela zákona o účetnictví definovala v $§ 1$ odst. 3 nový pojem vybrané účetní jednotky. Mezi vybrané účetní jednotky patří zdravotní pojišt'ovny a některé vybrané účetní jednotky (dále jen NVÚJ), kterými jsou:

- organizační složky státu, ${ }^{1}$

- státní fondy podle rozpočtových pravidel,

- Pozemkový fond České republiky,

- územní samosprávné celky, dobrovolné svazky obcí,

- Regionální rady regionů soudržnosti a

- př́íspěvkové organizace.

Zákon o účetnictví a navazující předpisy vybraným účetním jednotkám definují zvláštní povinnosti týkající se účetní závěrky, účetních metod, inventarizace majetku a závazků, vedení účetnictví a zjišstování a přenosu účetních záznamů pro potřeby státu. Dalším významným ustanovením zákona o účetnictví pro vybrané účetní jednotky je doplnění $§ 1$ o odstavce 3 a 4, které: „stanoví podmínky zjištování účetních záznamů pro potřeby státu. Zjišstováním účetních záznami̊ pro potřeby státu se rozumí soubor činností, které směrují ke shromažd'ování účetních záznamů od vybraných účetních jednotek v centrálním systému účetních informací státu a $k$ sestavení účetních výkazů za Českou republiku. " Proces přenosu dat do centrálního systému účetních informací státu (dále jen CSÚIS) je upraven vyhláškou č. 383/2009 Sb., o účetních záznamech v technické formě vybraných účetních jednotek a jejich předávání do centrálního systému účetních informací státu a o požadavcích na technické a smíšené formy účetních záznamů (technická vyhláška).

Konsolidované účetní závěrce jsou v zákoně o účetnictví vyhrazeny $§ 22$ až $§ 23 a$. Pro vybrané účetní jednotky s účinností od 1. 1. 2010 byl do zákona vložen nový § 23b, který upravuje sestavování účetních výkazů za Českou republiku a který stanoví, že ustanovení § 22 až 23a se na NVÚJ nevztahují. Ustanovení § 23b odst. 5 zní:

„Podminky způsobu sestavení ročních účetních výkazů a mezitímních účetních výkazů za Českou republiku, zejména vymezení konsolidačního celku a dílčích konsolidačních celkủ

\footnotetext{
${ }^{1}$ URBANCOVÁ, A.; KRYŠKOVÁ, Š. Účetnictví nevýdělečných organizací A. 2. vyd. Ostrava: VŠB Technická univerzita, 2008. 232 str. ISBN 978-80-248-1801-6.
} 
státu, stanovení pravidel konsolidace, včetně pravidel pro prenos účetních záznamů $v$ technické formě, a dále způsobu a rozsahu použití metod konsolidace a určení odchylek stanoví prováděcí právní předpis. " Podle harmonogramu účetní reformy je proces konsolidace rozdělen na dvě etapy a vyhláška o konsolidaci zatím nebyla vydána.

Od 1. 1. 2010 došlo také ke změně znění § 14 zákona o účetnictví (Směrná účtová osnova a účtový rozvrh). V odstavci 1 byla přidána věta tohoto znění: „Pro vybrané účetní jednotky může směrná účtová osnova určit i uspořádání a označení analytických účtů a označení a uspořádání podrozvahových účtů. " Podle $\$ 76$ vyhlášky je uspořádání směrné účtové osnovy pro některé vybrané účetní jednotky v následujícím členění: třída, skupina a účet. Toto členění (Příloha č. 7 vyhlášky č. 410/2009 Sb.) je závazné pro všechny účetní jednotky, včetně př́íspěvkových organizací, které mohou vést účetnictví ve zjednodušeném rozsahu.

Od roku 2010 se podstatně zúžil počet účetních jednotek, které mohou vést účetnictví ve zjednodušeném rozsahu. Účetnictví ve zjednodušeném rozsahu mohou vést z okruhu některých vybraných účetních jednotek pouze prríspěvkové organizace, u nichž o tom rozhodne jejich zřizovatel ( $\$ 9$ odst. 3 a 4). Požadavky na vedení účetnictví ve zjednodušeném rozsahu jsou obsaženy v $§ 13 a$ zákona o účetnictví (účtový rozvrh v rozsahu třída a skupina, spojení účtování $\mathrm{v}$ deníku $\mathrm{s}$ účtováním v hlavní knize, tvorba pouze zákonných rezervy a opravných položek, účetní jednotky sestavují závěrku ve zjednodušeném rozsahu, nemusí provádět zápisy v knihách analytických a podrozvahových účtů). Zákon sice umožňuje sestavit účtový rozvrh v rozsahu třída a skupina, ale vyhláška, jak už bylo zmíněno nikoliv. Rozsah vedení účetnictví má také vliv na rozsah účetní závěrky (\$ 9 vyhlášky č. 410/2009 Sb.). Př́íspěvkové organizace, které vedou účetnictví ve zjednodušeném rozsahu a jejichž zrrizovatelem je územní samostatný celek nebo dobrovolný svazek obcí nesestavují:

- přehled o peněžních tocích,

- přehled o změnách vlastního kapitálu.

Povinnost inventarizace majetku a závazků byla do konce roku 2010 zakotvena jen v zákoně č. 563/1991 Sb., o účetnictví, ve znění pozdějších předpisů (§ 29 a $§ 30$ ). V souladu s ustanovením $\S 29$ odst. 4 a $\S 30$ odst. 5 zákona č. 563/1991 Sb., o účetnictví, ve znění pozdějších předpisů, byla v roce 2010 vydána vyhláška č. 270/2010 Sb., o inventarizaci majetku a závazků, kterou se řídí pouze vybrané účetní jednotky. Účinnost tohoto prováděcího právního předpisu nastala dne 5. 10. 2010. V přechodných ustanoveních vyhlášky ( $\$ 17)$ je uvedeno, že vybrané účetní jednotky nepoužijí ustanovení této vyhlášky pro inventarizace zahájené před 1 . lednem 2011. Dle $\S 17$ odst. 2 bylo umožněno vybraným účetním jednotkám použít přiměřeně ustanovení vyhlášky i pro inventarizace související s účetním obdobím roku 2010.

\subsection{Vyhlášky pro některé vybrané účetní jednotky}

Zákon o účetnictví předpokládá existenci několika prováděcích vyhlášek ${ }^{2}$, které dále rozvádějí vybraná ustanovení zákona o účetnictví pro různé typy účetních jednotek. Vyhlášky pro některé vybrané účetní jednotky platné po 1. 1. 2010 jsou uvedeny v Tab. 1.1. Vzhledem k obsáhlosti a závažnosti obsahu reformy byly stěžejní dvě vyhlášky a to prováděcí vyhláška č. 410/2009 Sb. k novelizovanému zákonu o účetnictví a technická vyhláška č. 383/2009 Sb. Obě vyhlášky však byly vydány krátce před jejich praktickou realizací, takže vybrané účetní jednotky neměly dostatek času prripravit se na nové změny a jejich aplikaci do svého účetnictví.

Tab. 1.1 Vyhlášky platné pro některé vybrané účetní jednotky po 1. 1. 2010

\footnotetext{
${ }^{2}$ § 4 odst. 8 zákona č. 563/1991 Sb., o účetnictví.
} 
- vyhlášena dne 11. listopadu 2010

- účinnost - dnem 1. ledna 2010

Vyhláška č. 435/2010 Sb., kterou se mění vyhláška č. 410/2009 Sb., kterou se provádějí některá ustanovení zákona č. 563/1991 Sb., o účetnictví, ve znění pozdějších předpisů, pro některé vybrané účetní jednotky

- vyhlášena dne 23. prosince 2010

- účinnost - dnem 1. ledna 2011

- část týkající se prvního použití metody opravných položek (s výjimkou pohledávek) a odpisování dlouhodobého majetku dnem jejího vyhlášení

Vyhláška č. 449/2009 Sb., o způsobu, termínech a rozsahu údajů předkládaných pro hodnocení plnění státního rozpočtu, rozpočtů státních fondů, rozpočtů územních samosprávných celků, rozpočtů dobrovolných svazků obcí a rozpočtů Regionálních rad regionů soudržnosti ${ }^{4}$

- vyhlášena dne 11. prosince 2009

- účinnost - dnem 1. ledna 2010

Vyhláška č. 403/2010 Sb., kterou se mění vyhláška č. 449/2009 Sb., o způsobu, termínech a rozsahu údajů předkládaných pro hodnocení plnění státního rozpočtu, rozpočtů státních fondů, rozpočtů územních samosprávných celků, rozpočtů dobrovolných svazků obcí a rozpočtů Regionálních rad regionů soudržnosti

- vyhlášena dne 21. prosince 2010

- účinnost - dnem 1. ledna 2011

Vyhláška č. 383/2009 Sb., o účetních záznamech v technické formě vybraných účetních jednotek a jejich prredávání do centrálního systému účetních informací státu a o požadavcích na technické a smíšené formy účetních záznamů (technická vyhláška)

- vyhlášena dne 27. ř́ína 2009

- účinnost - dnem 1. ledna 2010

Vyhláška č. 434/2010 Sb., kterou se mění vyhláška č. 383/2009 Sb., o účetních záznamech v technické formě vybraných účetních jednotek a jejich předávání do centrálního systému účetních informací státu a o požadavcích na technické a smíšené formy účetních záznamů (technická vyhláška o účetních záznamech)

- vyhlášena dne 23. prosince 2010

- účinnost - dnem jejího vyhlášení

Vyhláška č. 323/2002 Sb., o rozpočtové skladbě ${ }^{5}$

(poslední aktualizace vyhláškou č. 357/2009 Sb.)

- vyhlášena dne 2. července 2002

- účinnost - dnem jejího vyhlášení

Zdroj: vlastní zpracování

\footnotetext{
${ }^{3}$ Touto vyhláškou byla zrušena vyhláška č. 505/2002 Sb., kterou se provádějí některá ustanovení zákona č. 563/1991 Sb., o účetnictví, ve znění pozdějších předpisů, pro účetní jednotky, které jsou územními samosprávnými celky, příspěvkovými organizacemi, státními fondy a organizačními složkami státu.

${ }^{4}$ Tato vyhláška nahradila vyhlášku č. 16/2001 Sb., o způsobu, termínech a rozsahu údajů předkládaných pro hodnocení státního rozpočtu, rozpočtů státních fondů a rozpočtů územních samosprávných celků (finanční výkazy).

5 Tato vyhláška se vztahuje na územní samosprávné celky, dobrovolné svazky obcí, organizační složky státu a státní fondy.
} 


\section{3 České účetní standardy}

Novelizací zákona o účetnictví došlo k další významné změně pro vybrané účetní jednotky, jak vyplývá ze znění § 36 odst. 1: „Pro dosažení souladu při používání účetních metod účetními jednotkami a pro zajištěni vyšši míry srovnatelnosti účetních závěrek ministerstvo vydává Ceské účetní standardy (dále jen „standardy“). Standardy stanoví zejména bližší popis účetních metod a postupu účtování. Vybrané účetní jednotky postupuji podle standardi̊ vždy. Ostatní účetní jednotky se mohou od standardů odchýlit, pokud tím zajistí věrný a poctivý obraz předmètu účetnictví..."

Tab. 1.2 obsahuje přehled Českých účetních standardů pro některé účetní jednotky. V roce 2010 bylo účetnictví některých vybraných účetních jednotek upraveno pouze 4 platnými standardy (701 - 704), v roce 2011 je to již 8 standardů, přičemž v roce 2009 platilo celkem 22 standardů. Z toho vyplývá velká míra nejistoty některých vybraných účetních jednotek při vedení jejich účetnictví v roce 2010 i 2011. Nabízí se otázka - jak postupovat při řešení účetních př́ípadů, které nejsou v účetních předpisech vůbec upraveny? Při hledání optimálního postupu mohou napomoci např́ílad informace zveřejňované na stránkách ministerstva financí ČR, metodická doporučení krajů apod. ${ }^{6}$ Praxe však ukazuje, že zveřejňované informace nabízejí rozdílné postupy účtování a tím i rozdílné zobrazení účetních skutečností v rozvaze a výkazu zisku a ztrát.

Tab. 1.2 České účetní standardy pro některé vybrané účetní jednotky, které vedou účetnictví podle vyhlášky č. 410/2009 Sb. (stav k 30. 6. 2011)

\begin{tabular}{|c|l|}
\hline $\begin{array}{c}\text { Č́íslo } \\
\text { standardu }\end{array}$ & \multicolumn{1}{|c|}{ Název standardu } \\
\hline $\mathbf{7 0 1}$ & Účty a zásady účtování na účtech \\
\hline $\mathbf{7 0 2}$ & $\begin{array}{l}\text { Otevírání a uzavírání účetních knih (součástí tohoto standardu je Převodový } \\
\text { můstek) }\end{array}$ \\
\hline $\mathbf{7 0 3}$ & Transfery \\
\hline $\mathbf{7 0 4}$ & Fondy účetní jednotky \\
\hline $\mathbf{7 0 5}$ & Rezervy \\
\hline $\mathbf{7 0 6}$ & Opravné položky a vyřazení pohledávek \\
\hline $\mathbf{7 0 7}$ & Zásoby \\
\hline $\mathbf{7 0 8}$ & Odpisování dlouhodobého majetku \\
\hline
\end{tabular}

Zdroj: vlastní zpracování

\section{2 Účetní metody}

Dle $\S 4$ odst. 8 zákona o účetnictví jsou účetní jednotky povinny při vedení účetnictví dodržovat mimo jiné i účetní metody stanovené prováděcími právními předpisy pro jednotlivé skupiny účetních jednotek. Tímto prováděcím předpisem je pro některé vybrané účetní jednotky vyhláška č. 410/2009 Sb., která nahradila dříve platnou vyhlášku č. 505/2002 Sb. Tato vyhláška obsahuje $\mathrm{v}$ třetí části některé účetní metody, které musí některé vybrané účetní jednotky uplatňovat při vedení svého účetnictví. Příspěvkové organizace většinu těchto účetních metod již ve svém účetnictví uplatňovaly před rokem 2010. Ostatní některé vybrané účetní jednotky budou „nové účetní metody“ postupně zavádět dle časového harmonogramu uvedeného $\mathrm{v}$ Tab. 2.1 a tedy $\mathrm{v}$ praxi naplňovat ustanovení zákona o účetnictví o věrném a poctivém obrazu předmětu účetnictví a finanční situaci účetní jednotky. Významným nástrojem určujícím, jak přistupovat $\mathrm{k}$ otázkám uplatnění nových účetních metod v účetní

\footnotetext{
${ }^{6} \mathrm{http}: / /$ www.mfcr.cz/cps/rde/xchg/mfcr/xsl/dane_ucetni_reforma_vf.html

${ }^{7}$ Jedná se o nové znění ČÚS 703 pod stejným číslem.
} 
praxi, je aplikace principu významnosti. Ustanovení $§ 19$ odst. 6 zákona o účetnictví považuje informaci za významnou, jestliže by její neuvedení nebo chybné uvedení mohlo ovlivnit úsudek nebo rozhodování osoby, která tuto informaci využívá. Pokud nejde o informaci předávanou do CSÚIS, může účetní jednotka rozhodnout o tom, pro jak významné operace bude některé účetní metody používat k datu sestavování mezitímních účetních závěrek.

Tab. 2.1 - Harmonogram aplikace účetních metod v praxi některých vybraných účetních jednotek

\begin{tabular}{|c|c|c|}
\hline Účetní metoda & $\begin{array}{c}\text { Vyhláška } \\
\text { č. 410/2009 Sb., }\end{array}$ & $\begin{array}{c}\text { Aplikace metody } \\
\text { § } 79 \text { Přechodná } \\
\text { ustanovení vyhlášky }\end{array}$ \\
\hline Odpisování dlouhodobého majetku & $\S 66$ & k 31. 12. 2011 \\
\hline $\begin{array}{l}\text { Tvorba opravných položek k majetku (s } \\
\text { výjimkou pohledávek) }\end{array}$ & $\S 65$ & k 31. 12. 2011 \\
\hline Tvorba opravných položek k pohledávkám & $\S 65$ & 2010 \\
\hline Tvorba účetních rezerv & $\S 67$ & 2010 \\
\hline $\begin{array}{l}\text { Ocenění reálnou hodnotou (např. cenné } \\
\text { papíry) }\end{array}$ & $\S 59$ & 2010 \\
\hline $\begin{array}{l}\text { Ocenění reálnou hodnotou - majetek určený } \\
\text { k prodeji, pokud k rozhodnutí o prodeji } \\
\text { došlo do } 31.12 .2009\end{array}$ & $\begin{array}{c}\S 64 \\
\S 79 \text { odst. } 4\end{array}$ & 31.12 .2010 \\
\hline Časové rozlišení nákladů a výnosů & $\S 69$ & 2010 \\
\hline
\end{tabular}

Zdroj: vlastní zpracování

\section{3 Účetní závěrka}

Ze změněné dikce zákona o účetnictví od 1. 1. 2010 je zřejmé, že účetní závěrka podnikatelských nebo nestátních neziskových organizací, může zahrnovat přehled o peněžních tocích nebo přehled o změnách vlastního kapitálu. Vybrané účetní jednotky sestavují (musí) přehled o peněžních tocích a přehled o změnách vlastního kapitálu. Pro srovnání jsou v Tab. 3.1 uvedeny požadavky na obsah účetní závěrky v letech 2009 - 2011. S účinností od 1. 1. 2011 byly „zmírněny“ podmínky pro sestavování přehledu o peněžních tocích a přehledu o změnách vlastního kapitálu. Povinnost sestavit tyto výkazy mají NVÚJ jestliže splní obě podmínky současně (úhrn aktiv i obratu). Dle stanoviska ministerstva financí tak nevzniká automaticky povinnost pro všechny NVÚJ sestavit přehled o peněžních tocích a přehled o změnách vlastního kapitálu za rok 2010, protože za rok 2009 NVÚJ bud' nevykazovaly žádné výnosy, z nichž by bylo možné vypočítat roční úhrn čistého obratu podle § 20 zákona o účetnictví nebo výnosy nepřesáhly hranici 80 mil. Kč (Zdroj: MF - odbor Účetnictví a audit, publikováno dne 21.1.2011). ${ }^{8}$

Technická vyhláška (č. 383/2009 Sb.) v Příloze č. 3 stanoví termíny pro předání jednotlivých součástí účetní závěrky takto:

- rozvaha, výkaz zisku a ztráty a př́loha

- čtvrtletně - ve stavu k 31. 3., 30. 6., 30. 9. - mezitímní účetní závěrka, a to do 20. dne následujícího měsíce a

- ročně, tj. ve stavu k 31.12. - řádná účetní závěrka, a to do 20. 2. následujícího roku,

- přehled o peněžních tocích a přehled o změnách vlastního kapitálu

\footnotetext{
${ }^{8}$ http://www.mfcr.cz/cps/rde/xchg/mfcr/xsl/sestaveni_ucetni_zaverky.html
} 
- ročně, tj. ve stavu k 31.12. - řádná účetní závěrka, a to do 20. 2. následujícího roku.

Tab. 3.1 - Účetní závěrka podle zákona o účetnictví a vyhlášky č. 410/2009 Sb.,

\begin{tabular}{|c|c|c|c|}
\hline \multicolumn{3}{|c|}{ Zákon o účetnictví } & $\begin{array}{l}\text { Vyhláška } \\
\text { č. 410/2009 Sb., }\end{array}$ \\
\hline $\begin{array}{c}\text { Stav k 31. } 12 . \\
2009\end{array}$ & Stav k 1. 1. 2010 & Stav k 1. 1. 2011 & Stav k 1. 1. 2011 \\
\hline $\begin{array}{l}\mathbf{1 8} \text { Účetní } \\
\text { závěrka } \\
\text { - rozvaha, } \\
\text { - } \quad \text { ýkaz zisku a } \\
\text { ztráty; } \\
\text { Pozemkový } \\
\text { fond České } \\
\text { republiky } \\
\text { a státní fondy } \\
\text { výkaz zisku } \\
\text { a ztráty } \\
\text { nesestavují, } \\
\text { př́loha. }\end{array}$ & \begin{tabular}{|l} 
\$ 18 Účetní \\
závěrka pro \\
vybrané účetní \\
jednotky \\
- rozvaha, \\
- výkaz zisku \\
a ztráty, \\
- příloha, \\
- přehled o \\
peněžních \\
tocích, \\
- přehled o \\
změnách \\
vlastního \\
kapitálu.
\end{tabular} & $\begin{array}{l}\text { \$ } 18 \text { Účetní závěrka } \\
\text { - NVÚJ sestavují přehled } \\
\text { o peněžních tocích a } \\
\text { přehled o změnách } \\
\text { vlastního kapitálu pokud } \\
\text { k rozvahovému dni a za } \\
\text { bezprostředně } \\
\text { předcházející účetní } \\
\text { období splní obě } \\
\text { kritéria uvedená } \\
\text { v } ~ 20 \text { odst. } 1 \text { písm. a) } \\
\text { bodech } 1 \text { a } 2: \\
\text { - } \text { aktiva více než } 40 \text { mil. } \\
\text { Kč, } \\
\text { - roční obrat více než } 80 \\
\text { mil. Kč. }\end{array}$ & $\begin{array}{l}\text { \$ } 3 \\
\text { Účetní závěrka pro } \\
\text { NVÚJ } \\
\text { \$ } \mathbf{4} \text { Rozvaha } \\
\text { \$ 5, } 42 \text { Výkaz } \\
\text { zisku a } \\
\text { ztráty } \\
\text { \$ 8, } 45 \text { Příloha } \\
\text { \$ 6, } 43 \text { Přehled } \\
\text { o } \\
\text { peněžních } \\
\text { tocích } \\
\text { \$ 7, } 44 \text { Přehled o } \\
\text { změnách } \\
\text { vlastního } \\
\text { kapitálu }\end{array}$ \\
\hline
\end{tabular}

Zdroj: vlastní zpracování

Rozvaha (Př́loha č. 1 vyhlášky č. 410/2009 Sb.) obsahuje aktiva k okamžiku sestavení mezitímní účetní závěrky nebo $\mathrm{k}$ rozvahovému dni v členění brutto, korekce (oprávky, opravné položky), netto a netto minulé období. Již v účetní závěrce za rok 2010 sloupec korekce může výrazně ovlivnit netto hodnotu aktiv prostřednictvím vyúčtovaných oprávek k drobnému nehmotnému a hmotnému majetku a opravných položek k pohledávkám. Za rok 2010 se pro srovnání jako minulé období výjimečně berou počáteční stavy k 1. 1. 2010 ( 79 odst. 5 vyhlášky č. 410/2009 Sb.), v souvislosti s př́vodovým můstek (vznik, zánik, přečíslování účtů) nemá význam srovnávat s konečnými zůstatky k 31. 12. 2009. Příloha č. 1 vyhlášky č. 410/2009 Sb., obsahuje závazný vzor rozvahy v členění na rozvahu:

- základní,

- pro organizační složky státu, pro územní samosprávné celky, svazky obcí, regionální rady regionů soudržnosti,

- př́spěvkové organizace,

- státní fondy a Pozemkový fond České republiky.

Výkaz zisku a ztráty (Př́loha č. 2 vyhlášky č. 410/2009 Sb.) obsahuje konečné zůstatky syntetických účtů nákladů a výnosů a výsledek hospodaření před a po zdanění v členění:

- za běžné a minulé období,

- za hlavní a hospodářskou činnost.

Hlavní činnost jsou veškeré činnosti, pro které byla účetní jednotka zřízena zvláštním předpisem, zřizovací listinou nebo jiným dokumentem. Hospodářskou činností se rozumí napřr. doplňková, vedlejší, podnikatelská nebo jiná činnost. 
Příloha č. 2 vyhlášky č. 410/2009 Sb., obsahuje závazný vzor výsledovky v členění na základní a pro jednotlivé typy některých vybraných účetních jednotek.

Příloha ( $\$ 8, \S 45$ vyhlášky) vysvětluje a doplňuje informace obsažené v ostatních částech účetní závěrky. Př́loha č. 5 vyhlášky č. 410/2009 Sb. obsahuje vzory příloh. Přehled o peněžních tocích obsahuje u vybraných položek aktiv a pasiv informace o přírůstcích a úbytcích peněžních prostředků. Obsah jednotlivých položek přehledu je specifikován v $§ 43 \mathrm{a}$ vzor přehledu je uveden v Př́loze č. 3 vyhlášky. Přehled o změnách vlastního kapitálu (vzor viz Př́loha č. 4 vyhlášky) obsahuje přehled o změnách vlastního kapitálu (jmění, fondy, výsledek hospodaření) v členění:

- stav k rozvahovému dni minulého období,

- zvýšení stavu v běžném účetním období,

- snížení stavu v běžném účetním období a

- stav k rozvahovému dni.

\section{Přezkoumání hospodaření a audit účetní závěrky}

\subsection{Přezkoumání hospodaření}

Zákon č. 420/2004 o přezkoumání hospodaření územních samosprávných celků a dobrovolných svazků obcí ( $\$ 1)$ upravuje přezkoumání hospodaření (územních celků):

- územních samosprávných celků,

- městských částí hlavního města Prahy,

- dobrovolných svazků obcí a

- Regionálních rad regionu soudržnosti.

Existují dva postupy zabezpečení přezkoumání prostřednictvím:

a) kontrolora (přezkoumání hospodaření prováděné krajským úřadem, ministerstvem financí),

b) auditora (§ 12).

Povinnost přezkoumání hospodaření územních celků je upravena v ustanovení $§ 4$ zákona o přezkoumání hospodaření a dále také v ostatních právních předpisech viz Tab. 4.1. Některé územní celky mají možnost volby mezi auditorem a kontrolorem, kraje a regionální rady regionu soudržnosti tuto možnost nemají, podléhají přezkoumání ministerstvem financí. Výstupem obou postupů je Zpráva o výsledku přezkoumání hospodaření a její náležitosti jsou uvedeny v $\S 7$.

Podle $\S 7$ odst. 3 zpráva kontrolora nebo auditora musí obsahovat vyjádření, zda při přezkoumání:

a) nebyly zjištěny chyby a nedostatky, nebo

b) byly zjištěny chyby a nedostatky, které nemají závažnost nedostatků uvedených pod písmenem c), anebo

c) byly zjištěny nedostatky, spočívajicí

1. v porušení rozpočtové káznè,

2. v neúplnosti, nesprávnosti nebo neprůkaznosti vedení účetnictví,

3. v pozměňování záznamů nebo dokladi̊ v rozporu se zvláštními právními předpisy,

4. v porušení povinností nebo překročení pưsobnosti územního celku stanovených zvláštními právními predpisy, 
5. v neodstranění nedostatků zjištěných při dílčím přezkoumání nebo při přezkoumání za predcházející roky, nebo

6. $v$ nevytvoření podmínek pro přezkoumání podle $\$ 7$ odst. 2, znemožňující splnit požadavky stanovené $v \S 2$ a 3.

Tab. 4. 1 - Právní úprava přezkoumání hospodaření územních celků

\begin{tabular}{|l|l|l|l|l|}
\hline Územní celek & \multicolumn{1}{|c|}{ Právní úprava } & \multicolumn{2}{c|}{$\begin{array}{c}\text { Přezkoumání } \\
\text { hospodaření } \\
\text { Provádí }\end{array}$} \\
\hline Kraj & zákon č. 129/2000 Sb., o krajích & $\S 20$ & $\begin{array}{c}\text { ministerstvo } \\
\text { financí }\end{array}$ & \\
\hline Obec & zákon č. 128/2000 Sb., o obcích & $\S 53$ & krajský úřad & Auditor \\
\hline $\begin{array}{l}\text { Hlavní město } \\
\text { Praha }\end{array}$ & $\begin{array}{l}\text { zákon č. 131/2000 Sb., o hlavním městě } \\
\text { Praze }\end{array}$ & $\S 38$ & $\begin{array}{c}\text { ministerstvo } \\
\text { financí }\end{array}$ & Auditor \\
\hline $\begin{array}{l}\text { Městské části } \\
\text { hlavního města }\end{array}$ & $\begin{array}{l}\text { zákon č. 131/2000 Sb., o hlavním městě } \\
\text { Praze }\end{array}$ & $\begin{array}{c}\text { magistrát } \\
\text { hlavního města }\end{array}$ & Auditor \\
\hline $\begin{array}{l}\text { Dobrovolné } \\
\text { svazky obcí }\end{array}$ & zákon č. 128/2000 Sb., o obcích & $\S 53$ & Arajský úřad & Auditor \\
\hline $\begin{array}{l}\text { Regionální } \\
\text { rady regionu } \\
\text { soudržnosti }\end{array}$ & $\begin{array}{l}\text { zákon č. 248/2000 Sb., o podpoře } \\
\text { regionálního rozvoje }\end{array}$ & $\S 16 a$ & $\begin{array}{c}\text { ministerstvo } \\
\text { financí }\end{array}$ & \\
\hline
\end{tabular}

Zdroj: vlastní zpracování

Jestliže se územní celek rozhodne zadat přezkoumání svého hospodaření auditorovi, uzavře s auditorem písemnou smlouvu o poskytnutí auditorských služeb, náklady na přezkoumání pak hradí ze svých rozpočtových prostředků. Své rozhodnutí musí územní celek ve lhůtě oznámit a zprávu o výsledku přezkoumání předat v souladu se zákonem o přezkoumání. V minulých letech se auditoři při přezkoumání hospodaření řídili:

- Auditorskou směrnicí č. 52 Přezkoumání hospodaření a audit účetní závěrky územních samosprávných celků,

- Pracovní pomůckou pro provádění přezkoumání hospodaření územních samosprávných celků a

- Metodická pomůckou pro přezkoumání hospodaření územních samosprávných celků a dobrovolných svazků obcí.

Komora auditorů vydala dva nové Auditorské standardy:

- Auditorský standard č. 52 Přezkoumání hospodaření a audit účetní závěrky územních samosprávných celků (účinnost od 23. 11. 2009, standard je neúčinný pro přezkoumání hospodaření za kalendářní rok 2011),

- Auditorský standard č. 52 Přezkoumání hospodaření územních samosprávných celků (standard je účinný pro přezkoumání hospodaření za kalendářní rok 2011, dřívější použití je doporučeno).

V souvislosti s reformou účetnictví státu a změnami zákona o účetnictví a prováděcích předpisů připravuje Výbor pro veřejný sektor Komory auditorů ČR aktualizaci metodické pomůcky pro přezkoumání hospodaření.

\section{Cíl přezkoumání hospodaření územního samosprávného celku}

Cílem je celkové zhodnocení rozpočtové hospodaření územního samosprávného celku. Není to pouhé posouzení věrohodnosti podávaných informací o hospodaření, ale posouzení 
hospodaření jako takového. Mezi součásti řádného hospodaření patř́i i řádné vedení účtů za účelem informování oprávněných stran, proto také je jednou ze součástí přezkoumání ověřování zveřejňovaných účetních a jiných informací. Tato část přezkoumání má nejblíže k ověřování účetní závěrky dle zákona o účetnictví, ačkoli není zcela identická.

\section{Přezkoumání hospodaření se skládá z těchto oblastí:}

a) Spolehlivost údajů o hospodaření (přezkum údajů) - v této části se přezkoumání zaměřuje na to, zda jsou uvedené údaje o činnosti územně samosprávných celků věrohodné a správné. Přezkum údajů je zaměřen na ověření zaznamenaných údajů o transakcích, zda jsou úplné, správné, spolehlivé apod.

b) Legalita a regulérnost hospodaření územně samosprávných celků (přezkum legality) v této části se ověřje, zda je hospodaření územně samosprávných celků v souladu s odpovídajícími právními ale i vnitřními předpisy (napřr. rozhodnutí zastupitelstva atd.) nebo smlouvami apod. Přezkum legality je zaměřen na posouzení právní korektnosti zaznamenaných transakcí.

c) Výkonnost hospodaření (přezkum výkonnosti) - v této části se přezkoumání zaměřuje na hospodárnost hospodaření územně samosprávných celků a účelnost hospodaření. Přezkum výkonnosti je zaměřen na přezkoumání kvality transakcí.

Přezkoumání hospodaření je ověřovací zakázkou v pojetí Mezinárodního rámce pro ověřovací zakázky. Auditor má při přezkoumání hospodaření územního samosprávného ocelku tyto cíle:

a) provést přezkoumání údajů o ročním hospodaření,

b) provést přezkoumání oblastí hospodaření dle př́slušných paragrafů zákona o přezkoumání,

c) na základě svých zjištění v souladu s příslušnými právními předpisy vydat zprávu.

Auditor je povinen naplánovat a provést zakázku na přezkoumání hospodaření tak, aby byly naplněny cíle přezkoumání hospodaření. Posuzuje soulad hospodaření územně samosprávných celků $\mathrm{s}$ př́slušnými právními předpisy a př́slušnými ustanoveními. Výsledkem přezkoumání hospodaření je zpráva o výsledku přezkoumání hospodaření dané účetní jednotky. Obsah zprávy a její zpracování vychází ze zákona o přezkoumání a Mezinárodního standardu pro ověřovací zakázky. Dle zákona o přezkoumání vyplývá, že zprávu o výsledku přezkoumání hospodaření je auditor povinen projednat:

a) se starostou (v případě obce nebo městské části hlavního města Prahy),

b) s primátorem (v př́ípadě statutárního města a hlavního města Prahy).

Auditor je dále povinen zvážit, zda je vhodné zprávu o výsledku přezkoumání hospodaření projednat i s finančním výborem zastupitelstva územního samosprávného celku. V př́ipadě dobrovolného svazku obcí je auditor povinen projednat zprávu s orgánem, který je k tomu určen stanovami svazku.

\subsection{Audit účetní závěrky}

Povinnost ověřování účetní závěrky stanoví zákona o účetnictví v ustanovení § 20. Pro NVÚJ je to $\S 20$ odst. 1 písm. e): ,účetní jednotky, kterým tuto povinnost stanoví zvláštní právní předpis. “ Povinnost ověření účetní závěrky auditorem státních fondů je upravena v př́slušném zákoně viz Tab. 4.2. ${ }^{9}$ Při overřování účetní závěrky se auditor řídí zejména zákonem č. 93/2009 Sb., o auditorech. Tento upravuje postavení a činnost statutárních auditorů, auditorských společností a asistentů auditora, postavení a působnost Komory

\footnotetext{
${ }^{9}$ Zákon č. 569/1991 Sb., o Pozemkovém fondu České republiky neupravuje povinnost auditu účetní závěrky Pozemkového fondu ČR.
} 
auditorů České republiky a Rady pro veřejný dohled nad auditem. Dále pak Mezinárodními auditorskými standardy a souvisejícími aplikačními doložkami Komory auditorů ČR.

Tab. 4.2 Státní fondy a povinnost ověřování účetní závěrky auditorem

\begin{tabular}{|c|c|c|}
\hline Státní fond & Právní úprava & $\begin{array}{c}\text { Povinnost ověřování } \\
\text { účetní závěrky auditorem }\end{array}$ \\
\hline $\begin{array}{l}\text { Státní fond } \\
\text { kultury České } \\
\text { republiky }\end{array}$ & $\begin{array}{l}\text { zákon č. 239/1992 Sb., } \\
\text { o Státním fondu kultury } \\
\text { České republiky }\end{array}$ & $\begin{array}{l}\text { \$ } \mathbf{6} \text { odst. } \mathbf{4} \\
\text { Fond vede účetnictví podle zvláštních předpisù } \\
\text { a zpracovává účetní závěrku, kterou ověruje } \\
\text { auditor. Náklady s tím spojené nese Fond. }\end{array}$ \\
\hline $\begin{array}{l}\text { Státní fond pro } \\
\text { podporu a } \\
\text { rozvoj české } \\
\text { kinematografie }\end{array}$ & $\begin{array}{l}\text { zákon č. } 241 / 1992 \mathrm{Sb} \text {., } \\
\text { o Státním fondu České } \\
\text { republiky pro podporu a } \\
\text { rozvoj české } \\
\text { kinematografie }\end{array}$ & $\begin{array}{l}\text { \$ } \mathbf{6} \text { odst. } \mathbf{4} \\
\text { Fond vede účetnictví podle zvláštních predpisů } \\
\text { a zpracovává účetní závěrku, kterou ověruje } \\
\text { auditor. Náklady s tím spojené nese Fond. }\end{array}$ \\
\hline $\begin{array}{l}\text { Státní } \\
\text { zemědělský } \\
\text { intervenční } \\
\text { fond }\end{array}$ & $\begin{array}{l}\text { zákon č. 256/2000 Sb., } \\
\text { o Státním zemědělském } \\
\text { intervenčním fondu }\end{array}$ & $\begin{array}{l}\text { \$ } 4 \text { odst. } 1 \\
\text { Fond je povinen } \\
\text { a) předkládat prostřednictvím ministerstva } \\
\text { vládé ve stanovených termínech rozpočet Fondu } \\
\text { na př́slušný kalendářní rok a ŕádnou účetní } \\
\text { závěrku, včetné přehledu pohledávek a závazkủ, } \\
\text { ověrenou auditorem, }\end{array}$ \\
\hline $\begin{array}{l}\text { Státní fond } \\
\text { dopravní } \\
\text { infrastruktury }\end{array}$ & $\begin{array}{l}\text { zákon č. } 104 / 2000 \mathrm{Sb} \text {., } \\
\text { o Státním fondu } \\
\text { dopravní infrastruktury }\end{array}$ & $\begin{array}{l}\text { \$ 5b odst. } 1 \\
\text { Po skončení rozpočtového roku sestavuje Fond } \\
\text { návrh roční účetní závěrky a výroční zprávy o } \\
\text { činnosti Fondu (dále jen "výroční zpráva") a } \\
\text { předkládá ji prostřednictvím ministra k } \\
\text { projednání vládě a ke schválení Poslanecké } \\
\text { sněmovně do tř́ měsíců po skončení } \\
\text { rozpočtového roku. Roční účetní závěrka Fondu } \\
\text { musí být před jejím předložením Poslanecké } \\
\text { sněmovně ověrena auditorem. }\end{array}$ \\
\hline $\begin{array}{l}\text { Státní fond } \\
\text { rozvoje bydlení }\end{array}$ & $\begin{array}{l}\text { zákon č. } 211 / 2000 \mathrm{Sb} \text {., } \\
\text { o Státním fondu rozvoje } \\
\text { bydlení }\end{array}$ & $\begin{array}{l}\text { \$ } 5 \text { odst. } 3 \\
\text { Po skončení kalendářního roku sestavuje Fond } \\
\text { roční účetní závěrku, kterou spolu s výroční } \\
\text { zprávou o činnosti Fondu předkládá ministr } \\
\text { vládě a vláda je předkládá do 31. března } \\
\text { běžného kalendářního roku ke schválení } \\
\text { Poslanecké sněmovně Parlamentu. Roční účetní } \\
\text { závěrka Fondu musí být pred jejím předložením } \\
\text { vládě ověrena auditorem. }\end{array}$ \\
\hline $\begin{array}{l}\text { Státní fond } \\
\text { životního } \\
\text { prostředí }\end{array}$ & $\begin{array}{l}\text { zákon č. } 388 / 1991 \mathrm{Sb} \text {., } \\
\text { o Státním fondu } \\
\text { životního prostředí }\end{array}$ & Zákon neupravuje \\
\hline
\end{tabular}

Zdroj: vlastní zpracování

\section{Cíl ověření účetní závěrky}

Cílem ověření účetní závěrky je zjistit, zda účetní závěrka podává věrný a poctivy obraz předmětu účetnictví v souladu s použitými právními předpisy a účetními standardy. Audit 
představuje provedení celé řady auditorských postupů za účelem získání důkazních informací o částkách a skutečnostech, uvedených v účetní závěrce dané účetní jednotky. Auditor na základě vlastního úsudku vybírá příslušné auditorské postupy a posuzuje rizika, zda v účetní závěrce nejsou uvedeny významné nesprávnosti, které by byly způsobeny podvodem či chybou. Při posuzování rizik se auditor zaměřuje na ověření funkčního vnitřního kontrolního systému, který je relevantní pro správné sestavení a věrné zobrazení účetní závěrky. Audit dále zahrnuje posouzení použitých účetních metod, přiměřenosti účetních odhadů provedených účetní jednotkou a posouzení celkové prezentace účetní závěrky. Při ověření účetní závěrky je auditor povinen dodržovat etické principy vymezené v etickém kodexu a naplánovat a provést audit s cílem získat přiměřenou jistotu, že účetní závěrka neobsahuje významné nesprávnosti.

V případě územních samosprávných celků (obec, kraj, hlavní město Praha), které nemají zákonnou povinnost ověření účetní závěrky auditorem, může přezkoumání hospodaření a audit může probíhat současně. Při ověření účetní závěrky auditor postupuje v souladu s Auditorským standardem č. 52.

O povinném auditu vyhotoví auditor písemnou zprávu auditora. Zpráva auditora kromě obecných náležitostí (úvod, obchodní firma nebo název a sídlo u auditovaných účetních jednotek, rozsah provedeného povinného auditu včetně odkazu na auditorské standardy) musí obsahovat, jak uvádí Hakalová: „výrok auditora, který musí jasně vyjádřit stanovisko auditora, zda účetní závěrka nebo konsolidovaná účetní závěrka podává věrný a poctivý obraz predmětu účetnictví v souladu s použitými právními předpisy a účetními standardy; výrok auditora je bud' bez výhrad, s výhradou, záporný, nebo je vyjádření výroku odmítnuto, jestliže auditor není schopný výrok auditora vyjádřit. “" Zprávu auditora projedná auditor se statutárním orgánem auditované účetní jednotky, součástí této zprávy je i vyjádření o ověření výroční zprávy a jejího souladu s účetní závěrkou.

Vydává-li auditor zprávu o ověrené výroční zprávy nebo konsolidované výroční zprávy, je povinen se vyjádřit $k$ souladu výroční zprávy s účetní závěrkou nebo konsolidované výroční zprávy s konsolidovanou účetní závěrkou. ${ }^{11}$

Přezkoumání hospodaření auditorem a audit účetní závěrky jsou dvě rozdílné auditorské činnosti. Přezkoumání hospodaření provádí krajský úřad ( $\mathrm{v}$ př́ípadě obcí nebo dobrovolných svazků obcí), nebo auditor či auditorská společnost, dále ho může provádět Ministerstvo financí ČR (v případě hlavního města Prahy, nebo Magistrát hlavního města Prahy v případě městské části hlavního města Prahy), nebo auditor či auditorská společnost. Audit (ověření) účetní závěrky provádí auditor či auditorská společnost. Výsledkem přezkoumání hospodaření je zpráva o výsledku přezkoumání hospodaření. Při auditu se auditor řídí jinými pravidly než při provádění přezkoumání hospodaření. Na základě provedeného auditu vydává auditor výrok k účetní závěrce.

\section{Závěr}

Reforma účetnictví veřejného sektoru představuje nezbytný a nezvratný proces, bohužel naplnění cílů reformy provázejí problémy v teorii i v praxi. $\mathrm{K}$ jejich řešení měly přispět další změny v zákoně o účetnictví, doplňující a zpřesňující ustanovení vyhlášky č. 410/2009 Sb., a především schválení a vydání dalších účetních standardů a vyhlášky ke konsolidaci.

\footnotetext{
${ }^{10}$ HAKALOVÁ, J. Účetní závěrka a auditing. 1. vyd. Brno: Tribun EU, 2010. 146 s. ISBN 978-80-7399-144-9.

11 § 20 odst. 2 zákona č. 92/2009 Sb., o auditorech a o změně některých zákonů (zákon o auditorech).
} 
Od 1. 1.2010 některé vybrané účetní jednotky zahájily účtování podle odlišné směrné účtové osnovy a „nových“ účetních metod. K datu zahájení účetní reformy nebyly pro některé vybrané účetní jednotky vypracovány všechny České účetní standardy, které mají stanovit bližší popis účetních metod a postupů účtování. K datu zahájení reformy byly přijaty pouze čtyři standardy, k datu 30. 6. 2011 je účetnictví některých vybraných účetních jednotek upraveno osmi standardy. V současné době je v připomínkovém řízení ministerstva financí konsolidační vyhláška, která předpokládá sestavování konsolidovaných účetních výkazů za Českou republiku. Oproti původnímu harmonogramu došlo k posunutí termínu pro první aplikaci metody odpisování a tvorby opravných položek k majetku (s výjimkou pohledávek) o jeden rok. Jak vyplývá z výše uvedeného, největším problémem je stav a komplexnost legislativního procesu. Většina právních norem je zveřejňována a schvalována na poslední chvíli s nemožností připravit se na chystané změny (zveřejnění ve Sbírce zákonů v prosinci, účinnost od 1. ledna). Také metodická podpora ze strany ministerstva financí a proškolení pracovníků některých vybraných účetních jednotek jak v oblasti účetnictví, tak i v oblasti výkaznictví nebyla dostatečná a to jak z hlediska časového, tak i objemu a kvality poskytovaných informací. Účetní jednotky na základě neúplných a často i protichůdných informací pak volily takový postup, který podle jejich názoru vedl k co nejvěrnějšímu zobrazení daných skutečností v účetnictví. Teprve následné výsledky přezkoumání hospodaření a audit účetních závěrek ukáže, zda účetní jednotky zvolily správný způsob řešení problému, tak aby jejich účetní závěrka podávala věrný a poctivý obraz předmětu účetnictví a finanční situace účetní jednotky.

\section{Literatura:}

[1] HAKALOVÁ, J. Účetní závěrka a auditing. 1. vyd. Brno: Tribun EU, 2010. 146 s. ISBN 978-80-7399-144-9.

[2] URBANCOVÁ, A.; KRYŠKOVÁ, Š. Účetnictví nevýdělečných organizací A. 2. vyd. Ostrava: VŠB - Technická univerzita, 2008. 232 s. ISBN 978-80-248-1801-6.

[3] AUDITOR, číslo 8, 2010. Ročník XVII. Komora auditorů ČR. ISSN 1210-9096.

[4] AUDITOR, číslo 10, 2010. Ročník XVII. Komora auditorů ČR. ISSN 1210-9096.

[5] Zákon č. 563/1991 Sb., o účetnictví, ve znění pozdějších předpisů

[6] Zákon č. 420/2004 o přezkoumání hospodaření územních samosprávných celků a dobrovolných svazků obcí, ve znění pozdějších předpisů,

[7] Zákon č. 93/2009 Sb., o auditorech a o změně některých zákonů (zákon o auditorech)

[8] Vyhláška č. 410/2009 Sb., kterou se provádějí některá ustanovení zákona č. 563/1991 Sb., o účetnictví, ve znění pozdějších předpisủ, pro některé vybrané účetní jednotky

[9] Vyhláška č. 383/2009 Sb., o účetních záznamech v technické formě vybraných účetních jednotek a jejich předávání do centrálního systému účetních informací státu a o požadavcích na technické a smíšené formy účetních záznamů (technická vyhláška)

[10] České účetní standardy pro některé vybrané účetní jednotky, které vedou účetnictví podle vyhlášky č. 410/2009 Sb. - ČÚS č. 701 - č. 708

[11] http://www.mfcr.cz/cps/rde/xchg/mfcr/xsl/dc2_ucetnictvi.html

[12] www.kacr.cz

JEL M41, M42, M48 
Ing. Jana Hakalová, Ph.D.

vedoucí katedry účetnictví

Katedra účetnictví

Ekonomická fakulta VŠB-TU Ostrava

Sokolská tř́ída 33

70121 Ostrava 1

jana.hakalova@vsb.cz

Ing. Alžběta Urbancová, Ph.D.

odborná asistentka

Katedra účetnictví

Ekonomická fakulta VŠB-TU Ostrava

Sokolská tř́ída 33

70121 Ostrava 1

alžběta.urbancova@vsb.cz 